\title{
Hypertrophic Obesity and Subcutaneous Adipose Tissue Dysfunction
}

\author{
Anna Meiliana ${ }^{1,2, *}$, Andi Wijaya ${ }^{2,3}$ \\ ${ }^{1}$ Postgraduate Program in Clinical Pharmacy, Padjadjaran University, Jl. Eijkman No.38, Bandung, Indonesia \\ ${ }^{2}$ Prodia Clinical Laboratory, Jl. Cisangkuy No.2, Bandung, Indonesia \\ ${ }^{3}$ Postgraduate Program in Clinical Biochemistry, Hasanuddin University, J1. Perintis Kemerdekaan Km.10, Makassar, Indonesia \\ *Corresponding author. E-mail: anna.meiliana@prodia.co.id
}

\section{Abstract}

B

ACKGROUND: Over the past 50 years, scientists have recognized that not all adipose tissue is alike, and that health risk is associated with the location as well as the amount of body fat. Different depots are sufficiently distinct with respect to fatty-acid storage and release as to probably play unique roles in human physiology. Whether fat redistribution causes metabolic disease or whether it is a marker of underlying processes that are primarily responsible is an open question.

CONTENT: The limited expandability of the subcutaneous adipose tissue leads to inappropriate adipose cell expansion (hypertrophic obesity) with local inflammation and a dysregulated and insulin-resistant adipose tissue. The inability to store excess fat in the subcutaneous adipose tissue is a likely key mechanism for promoting ectopic fat accumulation in tissues and areas where fat can be stored, including the intra-abdominal and visceral areas, in the liver, epi/pericardial area, around vessels, in the myocardium, and in the skeletal muscles. Many studies have implicated ectopic fat accumulation and the associated lipotoxicity as the major determinant of the metabolic complications of obesity driving systemic insulin resistance, inflammation, hepatic glucose production, and dyslipidemia.

SUMMARY: In summary, hypertrophic obesity is due to an impaired ability to recruit and differentiate available adipose precursor cells in the subcutaneous adipose tissue. Thus, the subcutaneous adipose tissue may be particular in its limited ability in certain individuals to undergo adipogenesis during weight increase. Inability to promote subcutaneous adipogenesis under periods of affluence would favor lipid overflow and ectopic fat accumulation with negative metabolic consequences.

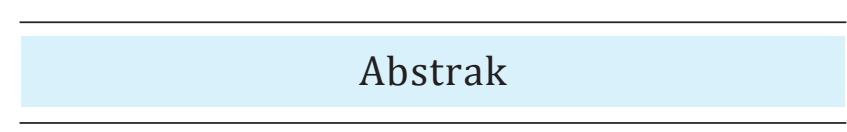

$\mathrm{L}$

ATAR BELAKANG: Telah lebih dari 50 tahun, para peneliti menyadari bahwa tidak semua jaringan adiposa adalah sama, dan bahwa risiko kesehatan berhubungan dengan jumlah dan lokasi adiposa tubuh. Perbedaan lokasi penyimpanan adiposa ini berkenaan dengan penyimpanan dan pelepasan asam adiposa sehingga dapat memainkan peran yang unik pada fisiologi manusia. Bagaimana redistribusi adiposa dapat menyebabkan penyakit metabolik, atau apakah hal ini merupakan penanda yang mendasari proses utama terjadinya penyakit, masih merupakan tanda tanya.

ISI: Kemampuan ekspansi jaringan adiposa subkutan yang terbatas, memicu terjadinya ekspansi sel adiposa yang tidak tepat (obesitas hipertrofi) disertai inflamasi lokal, disregulasi jaringan adiposa dan resistensi insulin. Ketidakmampuan menyimpan kelebihan adiposa pada jaringan adiposa subkutan merupakan mekanisme kunci yang mengawali akumulasi adiposa ektopik pada jaringan dan area dimana adiposa dapat disimpan, termasuk area intra-abdominal dan viseral, hati, area epi/perikardial, sekitar pembuluh darah, miokardium, dan otot skeletal. Banyak penelitian yang menunjukkan hubungan akumulasi adiposa ektopik dengan lipotoksisitas sebagai penentu utama komplikasi metabolik pada obesitas yang menyebabkan resistensi insulin sistemik, inflamasi, produksi glukosa hepatik, dan dislipidemia.

RINGKASAN: Secara ringkas, obesitas hipertrofi berkaitan dengan ketidakmampuan sel prekursor adiposa yang tersedia pada jaringan adiposa subkutan untuk merekrut dan berdiferensiasi. Dengan demikian, jaringan adiposa subkutan memiliki keterbatasan dalam hal adipogenesis selama proses peningkatan beran badan. Ketidakmampuan untuk meningkatkan adipogenesis subkutan pada periode 
KEYWORDS: obesity, adipogenesis, subcutaneous adipose tissue, visceral adipose tissue, adipocyte dysfunction

Indones Biomed J. 2014; 6(2): 79-90 yang lama akan menimbulkan luapan adiposa dan akumulasi adiposa ektopik, dengan konsekuensi metabolik yang negatif.

KATA KUNCI: obesitas, adipogenesis, jaringan adiposa subkutan, jaringan lemak viseral, disfungsi adiposit

\section{Introduction}

The current global epidemic of obesity is a huge challenge to society and imposes increasing costs on the health care system because obesity is associated with several negative consequences to our health, including type 2 diabetes mellitus (T2DM), cardiovascular disease, and cancer.(1) However, it is not only the degree of obesity that is important but also the distribution of fat; an abdominal distribution augments the metabolic complications at a given body mass index (BMI).(2) This finding has raised much interest in the potential role of regional differences in adipose tissue metabolism and, in particular, the role of intra-abdominal and visceral fat in causing the metabolic complications. $(3,4)$ However, increased amounts of intra-abdominal/visceral fat is also associated with other ectopic fat accumulations and may, thus, be a marker rather than causally related to the metabolic complications of obesity.(5)

Certain subcutaneous fat regions appear to be metabolically, immunologically, and mechanically protective. Subcutaneous fat, which can expand outward without the anatomic constraints that limit visceral fat growth, is specialized to provide long-term fuel storage, acting as a sink to sequester potentially lipotoxic fatty acids.(6-8) Consistent with its role in energy storage, subcutaneous fat is the major source of leptin, which signals the state of lipid stores to the brain. Dysfunctional subcutaneous fat is associated with visceral fat enlargement, systemic inflammation, and lipotoxicity.(7) Interestingly, subcutaneous fat abundance increases when visceral fat is removed from experimental animals.(9) When subcutaneous fat is removed, visceral fat mass, insulin resistance, circulating insulin, and tumor necrosis factor (TNF)- $\alpha$ increase. This may contribute to the visceral fat enlargement that occurs in tandem with subcutaneous fat loss in lipodystrophies and aging or subcutaneous fat dysfunction in obesity.(10)

Inappropriate expansion of the subcutaneous adipose cells leads to hypertrophic obesity characterized by a dysregulated adipose tissue with insulin resistance and inflammation. Here, we discuss the limited expandability of the subcutaneous adipose tissue, which, when exceeded, promotes ectopic fat accumulation and metabolic complications.

\section{Adipose Tissue in Different Fat Depots}

Adipose tissue can be divided into two major types: white adipose tissue (WAT) and brown adipose tissue (BAT), both of which have different physiological roles ascribed to them. Subcutaneous adipose tissue (SAT) and visceral adipose tissue (VAT) are two types of WAT. Although it has been reported that SAT is less metabolically active than VAT, it is an important storage organ, implicated in the accumulation of triacylglycerols (TGs) during periods of excess energy intake, and the supply of free fatty acids (FFAs) during periods of fasting, starvation, or exercise. SAT also serves as a buffer during intake of dietary lipids and thus protects other tissues from lipotoxic effects of these lipids.(11) VAT can be omental or mesenteric, and it surrounds various inner organs in humans. The omental fat depot covers the stomach and spleen and extends into the ventral abdomen, while the mesenteric depot is attached to the intestine.(12) BAT is found in defined and dispersed areas in the body such as clavicular, supraclavicular, and subscapular regions (10) or as clusters within WAT in different animals.(13) The main role of BAT is reported to be nonshivering thermogenesis in mammals, with this role in humans being particularly important in neonates.(14)

Human epicardial adipose tissue (EAT) is a visceral thoracic fat depot with proximity to the heart, and is located along the large coronary arteries and on the surface of ventricles and the apex of the heart.(15-17) EAT has been defined as the intrapericardial fat depot that is located between the myocardium and visceral pericardium, while the storage of TGs droplets within the cardiomyocytes have been termed myocardial fat.(18) The fat surrounding the vasculature has also been termed perivascular adipose tissue (PVAT), irrespective of location.(19)

Marrow fat or marrow adipose tissue (MAT) is well established as a component of the bone marrow (BM) environment, but its function remains unknown. In clinical 
studies of healthy populations as well as in populations of individuals with metabolic disease, MAT has been shown to be inversely associated with measures of bone mineral density (BMD) and bone integrity and therefore may be an important regulator of bone turnover.(20)

The principal function of adipose tissue is to store and release fat in response to energy-balance needs. Adipose tissue also has immune, endocrine, regenerative, mechanical, and thermal functions.(8) Both the fuel and nonfuel functions of adipose tissue vary among depots, with depot size, and with body-fat distribution. Potentially, when dysregulation of fatty-acid storage and release occurs in upper-body obesity, fatty-acid overflow into "ectopic" sites leads to lipotoxicity.(7) In addition to their role as major sources of cellular fuel, fatty acids can serve as signaling molecules in the form of diacylglycerols, ceramides, and long-chain acyl-coenzymes A. These molecules can exert adverse effects on cell function, including interference with insulin signaling, when present in excess.(10)

During weight gain, different fat depots enlarge via hyperplasia, hypertrophy, or both.(21) New adipocytes can be generated more rapidly in some depots than others. Regional differences in preadipocyte replication, differentiation, subtype abundance, susceptibility to apoptosis or senescence, and gene expression may contribute to regional variation in fat-tissue function.(22)

Obesity, aging, and lipodystrophies are associated with sustained fat-tissue immuneresponse activation, proinflammatory cytokine release, impaired insulin responsiveness, reduced incorporation of fatty acid as triglycerides, and increased lipolysis. $(8,22)$ This contributes to low-grade "sterile" systemic inflammation, metabolic dysregulation, and lipotoxicity, with different fat depots potentially contributing in distinct ways.

\section{Adipogenesis}

WAT is perhaps the most plastic organ in the body, capable of regeneration following surgical removal and massive expansion or contraction in response to altered energy balance.(23) This striking degree of plasticity is unique among organs in adults. On a cellular level, WAT expansion is driven by both hypertrophy and hyperplasia of adipocytes.(24-30) Even in nonexpanding WAT, adipocytes renew frequently to compensate for adipocyte death, with approximately $10 \%$ of adipocytes renewed annually.(30,31)

Both adipocyte hypertrophy and hyperplasia occur during normal growth phases and during the development of obesity.(29,32-34) Hypertrophy often precedes hyperplasia in a cyclic manner. Hyperplasia, herein referred to as "adipogenesis," represents the complex process by which new fat cells are developed from adipocyte precursor fat cells called preadipocytes. Adipogenesis involves two major events - the recruitment and proliferation of preadipocytes followed by their subsequent differentiation into mature fat cells.(35-37) "Proliferation" refers to the process by which preadipocytes replicate so as to increase fat cell number, whereas "differentiation" refers to the process by which undifferentiated, proliferating fibroblast-like preadipocytes

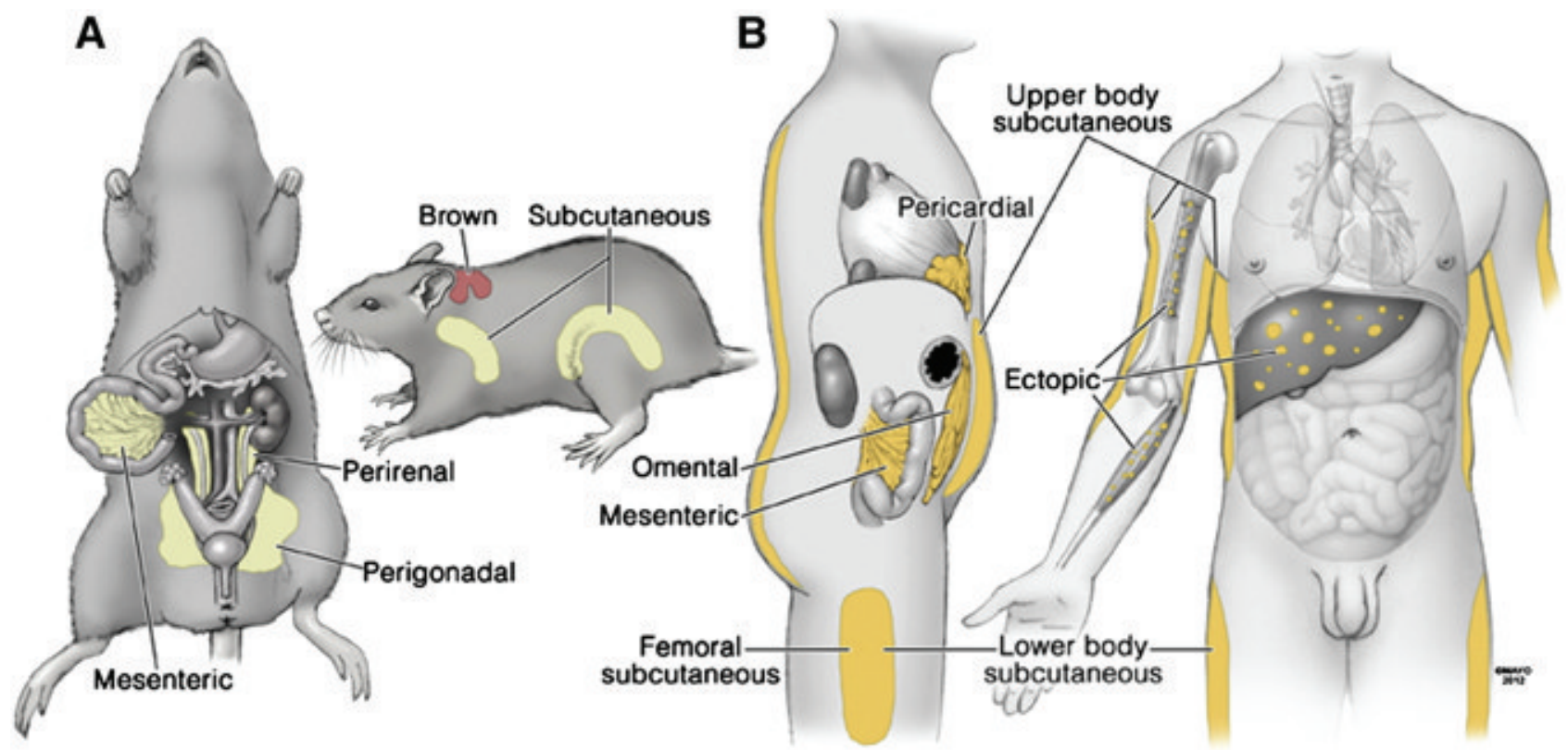

Figure 1. Anatomy of major fat depots in rodents and humans.(10) (Adapted with permission from Elsevier). 


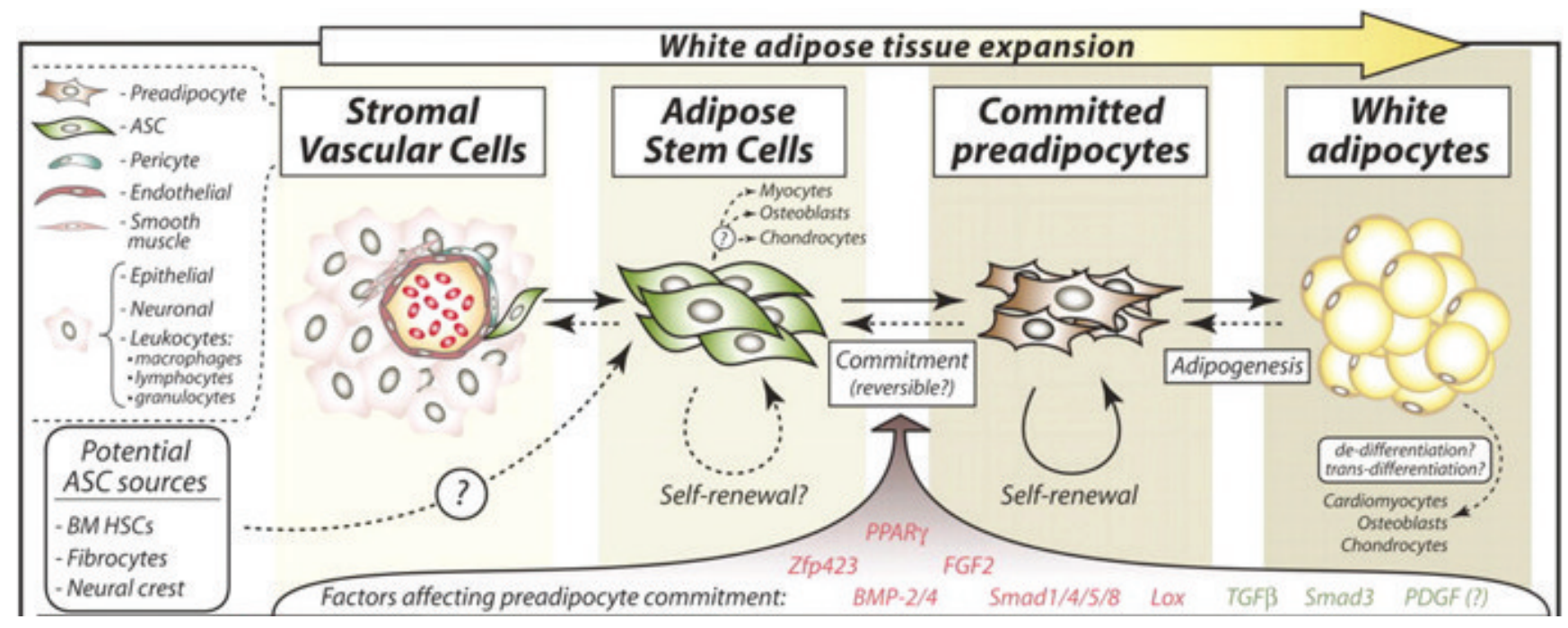

Figure 2. Relationships between SVCs, ASCs, committed preadipocytes, and mature adipocytes.(23) (Adapted with permission from The American Society for Biochemistry and Molecular Biology).

become permanently cell cycle - arrested, spherical, lipidfilled and functionally mature fat cells.(35) Differentiation is accompanied by dramatic alterations in cell shape as well as by molecular changes that lead to dramatic increases in the ability of the cell for lipid synthesis and increases in hormonal responsiveness specific to the specialized role of the adipocyte in energy homeostasis.(37-39)

Following the development of methods for separating WAT into adipocyte and stromal vascular fractions (SVFs). (40) Studies reported growth of fibroblast-like cells from the SVFs are capable of adipogenesis.(41-43) This led to the designation of these stromal vascular cells (SVCs) as "primary" preadipocytes, setting the stage for extensive characterization of the mechanisms regulating adipogenesis and WAT expansion.

The use of cell lines has facilitated extensive investigation of adipogenesis on a molecular level, leading to detailed characterization of extracellular modulators, intracellular signaling pathways, and, notably, transcriptional mechanisms that impact and underlie adipocyte differentiation. These developments have been reviewed extensively elsewhere (44-48) and continue to be refined and extended to this day, especially through global profiling of epigenetic modifications and transcription factor binding sites using DNase hypersensitivity, chromatin immunoprecipitation(ChIP)-on-chip (ChIP-chip) or ChIP sequencing (ChIP-seq) analysis (49-52). Thus, the study of both SVC and preadipocyte lines has made an enormous contribution to our current understanding of adipogenesis and WAT biology.(23)

The basic pathways regulating adipogenesis, focusing on the limited expandability of SAT and the development of hypertrophic obesity with a dysregulated adipose tissue and ectopic fat accumulation. Understanding mechanisms that limit subcutaneous adipogenesis in humans should provide novel targets for the treatment of obesity-related metabolic complications. It is well established that subcutaneous adipose cell size can differ markedly between individuals with the same BMI and amount of body fat,(53) supporting the concept that adipogenesis is under differential regulation. Interestingly, poor differentiation was seen in individuals with large subcutaneous adipose cells (hypertrophic obesity), whereas small adipose cells were associated with good adipogenesis suggesting a causal relationship. As discussed below, this difference was not due to a lack of precursor cells in hypertrophic obesity but rather due to inappropriate signaling of pathways that promote precursor cell differentiation and/or enhanced inhibitory signals promoting dedifferentiation, as has been suggested to be the case for $\beta$-cells in diabetes.(53)

A key signaling pathway for maintaining precursor cells uncommitted and undifferentiated is the wingless type mouse mammary tumor virus integration site family (WNT) signaling pathway. $(54,55)$ The transcriptional program regulating subsequent differentiation is well characterized, peroxisome proliferator-activated receptors (PPAR)- $\gamma$ and CCAAT/enhancer-binding protein- $\alpha$ have been identified as the key regulators of terminal differentiation. $(56,57)$ However, there is an array of other regulatory factors of importance for this process.

WNT activation can be terminated by several secreted antagonists, including Dickkopf-1 (DKK1), WNT inhibitory factor-1, and secreted Frizzled-related proteins (sFRPs), although the exact mechanisms for the regulation and induction of these molecules are unclear. We have shown that PPAR $\gamma$ activation by thiazolidinediones increases 
DKK1 in differentiated 3T3-L1 adipocytes.(58) However, this is obviously a late event and cannot account for the necessary early termination of WNT signaling needed to induce adipogenesis from precursor cells.

Gustafson et al. recently performed a detailed study to characterize WNT activation and its termination during adipogenic differentiation of human subcutaneous adipose precursor cells from different donors.(59) These findings show that a poor ability of adipose precursor cells to differentiate is associated with markers of a maintained WNT activation and lack of induction of the secreted WNT inhibitor DKK1. Furthermore, inhibiting WNT with DKK1 increases adipogenic differentiation, showing that the low ability to differentiate is not due to lack of precursor cells but rather to an inability to terminate WNT activation. A low degree of differentiation characterizes adipose precursor cells from individuals with large adipose cells suggesting that hypertrophic obesity is indeed a consequence of the impaired ability of precursor cells to differentiate.(5)

The BMPs have been shown to play an important role for the induction of both white adipogenesis (BMP2 and 4) and brown adipogenesis (BMP7).(59-61) Not only is BMP4 able to promote both commitment and subsequent differentiation when added to the culture medium but, interestingly, BMP4 is also induced in human adipose precursor cells during differentiation.(59)

Taken together, both WNT and BMP4 signaling play important roles in adipogenesis by regulating commitment as well as subsequent PPAR $\gamma$ activation and differentiation. BMP4 promotes commitment and adipogenic differentiation of precursor cells, whereas canonical WNT activation is inhibitory to both these processes. The WNT1 inducible signaling pathway protein-2 (WISP2) plays a key role by both preventing the effect of BMP4 to induce precursor cell commitment as well as by exerting a direct extracellular inhibitory signal on PPAR $\gamma$ activation and adipose cell differentiation after its secretion. Thus, WISP2 is situated at the crossroad between WNT and BMP4 signaling and can play a critical role for the development of hypertrophic obesity.

\section{Obesity, Hypertrophic Obesity and Metabolically Healthy Obesity}

Obesity is characterized by an expansion of WAT mass resulting from increased adipocyte number and/ or size.(62) It is a key risk factor leading to T2DM and hyperlipidemia, and has become a pan-endemic health problem with rapidly growing global incidence. $(46,63)$ Obesity is associated with systemic chronic inflammation characterized by altered cytokine production and activation of inflammatory signaling.(64,65) Abundant studies have linked the increased production of inflamatory cytokines, such as TNF- $\alpha$, interleukin (IL)- 6 , and certain adipokines, during the inflammatory process to obesity, as well as to the development of insulin resistance.(66-68) Obesity characterized by inappropriate expansion of adipose cells (hypertrophic obesity) is associated with the metabolic syndrome (MetS) and is caused by an inability to recruit and differentiate new precursor cells.(59)

Interestingly, research has also shown that individuals with inappropriately enlarged adipose cells for a given BMI (hypertrophic obesity) in the abdominal subcutaneous tissue are characterized by a reduced recruitment of new cells, suggesting that this is causally related to the development of hypertrophic obesity.(53) More important, adipose cell size in the abdominal subcutaneous region is, for a given BMI, considerably larger in individuals with a genetic predisposition for T2DM than in subjects lacking a known heredity or in those with a heredity for overweight/obesity. $(69,70)$ Furthermore, hypertrophic adipocytes, even in the absence of obesity per se, are associated with several markers of a dysregulated adipose tissue and systemic as well as local insulin resistance. $(70,71)$

In agreement with these in vivo findings, Isakson $\mathrm{P}$, et al. recently showed that the ability of SAT SVC to undergo adipogenic differentiation was markedly reduced in hypertrophic obesity and that the degree of impairment was positively correlated with adipose cell size of the donor. (55)

Together, these findings suggest that hypertrophic obesity is due to an apparent genetic impairment in the ability to recruit and differentiate new subcutaneous adipose precursor cells. This, then, promotes inappropriate cell enlargement, inflammation, and a dysregulated adipose tissue that will favor ectopic lipid accumulation and the development of a metabolically obese phenotype. $(69,70)$ The concept of lipid storage "overflow" as a consequence of the limited expansion of SAT has received much experimental support in both human and animal studies. The animal model generated by Scherer, et al. (72) with overexpression of adiponectin in SAT, induced massively obese mice with perfectly normal insulin sensitivity and metabolism. Importantly, the adipose tissue in these mice was characterized by many small adipose cells-hyperplastic obesity. These and many other studies support the concept that the ability to recruit new adipose cells in SAT during lipid accretion prevents inappropriate adipose cell expansion 
(hypertrophic obesity) with infiltration of inflammatory cells, insulin resistance, and a dysfunctional adipose tissue with reduced insulin receptor substrate 1, glucose transporter, type 4 (GLUT4), lipoprotein lipase activation, adiponectin, and other markers of reduced PPAR $\gamma$ activation. $(73,74)$ The recruitment and activation of the inflammatory cells in the adipose tissue may be a consequence of both necrotic enlarged adipose cells and tissue factors promoting a proinflammatory phenotype. $(75,76)$

Hypertrophic obesity is associated with inflammation and increased cytokine production and release, which can inhibit PPAR $\gamma$ activation, the key mediator of the fully differentiated and insulin-sensitive adipose cell phenotype. (55) Overall, the adipose tissue becomes dysfunctional both in terms of taking up lipids from the bloodstream via lipoprotein lipase activation, secreting adiponectin and other apparently protective adipokines and, instead, increasing the secretion of insulin-antagonistic and proinflammatory molecules also associated with increased lipolysis and FFA release.(5)

Promoting adipose cell recruitment in SAT rather than merely inflating the cells would be protective of the obesity-associated metabolic complications. In fact, this is a fundamental mechanism of action of the thiazolidinediones,(77) also leading to reduced ectopic fat while the subcutaneous depot becomes expanded and less insulin resistant, $(77,78)$ but their unwanted side effects have

\begin{tabular}{|c|c|c|}
\hline & Lean Body Type & Obese Body Type \\
\hline 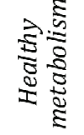 & $\begin{array}{l}\text { Lean, } \\
\text { Healthy }\end{array}$ & МHO \\
\hline 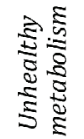 & MONW & $\begin{array}{c}\text { Obese, } \\
\text { Unhealthy }\end{array}$ \\
\hline
\end{tabular}

Figure 3. A classification model for obese and metabolic phenotypes. A 'two-by-two' map of the effects of obesity on health, with two off-diagonal entries.(79) MONW: metabolically obese normal weight; MHO: metabolically healthy obese. (Adapted with permission from Elsevier).

limited the usefulness of this class of drugs.

Obesity is a major public health problem that has reached epidemic proportions worldwide.(80) It is associated with numerous metabolic and cardiovascular disturbances such as insulin resistance, T2DM, hypertension, and dyslipidemia.(81-84) However, these cardiometabolic abnormalities are not found in all obese people $(85,86)$, as evidenced by the occurrence of a subset of apparently healthy obese subjects referred to as metabolically healthy obese (MHO).(87,88) Several studies have confirmed the existence of MHO individuals (89-95), accounting for as much as $40 \%$ of the obese population. MHO individuals display a favorable metabolic profile, characterized by high levels of insulin sensitivity, a low prevalence of hypertension, and a favorable lipid and inflammation profile. The MHO phenotype is strongly associated with a smaller visceral depot, although not necessarily with expanded subcutaneous; the clamped glucose infusion rate strongly correlates with visceral WAT area.(96)

In humans, WAT fibrosis as measured by collagen VI expression is positively correlated with insulin resistance and inflammatory markers, such as the number of adipose tissue macrophages (ATMs).(97) The relationship between stress/fibrosis and unhealthy WAT (98) supports a hypothesis that alleles of genes that encode different forms of collagen or enzymes that modify collagen, such as lysyl oxidase,(99) correlate with the ability of WAT to expand and remodel in obesity while avoiding stress and remaining metabolically healthy.

A hypothesis follows that some MHO humans will show increased adipogenesis, based on functional allelic variants of PPAR $\gamma$, peroxisome proliferator-activated receptor gamma coactivator 1 - alpha (PGC-1 $\alpha$ ), PR domain containing (PRDM) 16 or other components of the adipogenic transcriptional program that expand subcutaneous WAT. (79)

\section{Adipocyte Stress, Endoplasmic Reticulum} Stress and Inflammation

Visceral storage capacity is relatively low compared to subcutaneous. Without available storage, lipid is distributed to hepatic, cardiac, skeletal muscle and other highly undesirable locations, called ectopic fat deposition (100), contributing to metabolic damage. Ectopic fat arises upon insufficient adipogenesis in the obese, prediabetic individual.(101)

Adipocytes are individually 'wrapped' in a supporting sheath of extracellular matrix (ECM), in particular collagens. Remodeling of the ECM, and cycles of collagen breakdown/ re-deposition in particular, are essential for adipocyte and adipose tissue expansion.(102) However, in the obese state, excessive, dysregulated deposition of collagens and other ECM components (i.e., fibrosis) eventually constrains adipocyte expansion, thereby promoting adipocyte stress, 
inflammatory/stress kinase activation, and resulting systemic metabolic dysfunction.(103-106)

Collagen VI is specifically implicated in the pathogenesis of obesity-associated adipose tissue fibrosis and metabolic dysfunction, as collagen VI deposition is increased in WAT of obese, insulin resistant humans,(97) and the absence of this ECM component in obese (knockout) mice permits greater adipocyte hypertrophy while normalizing key metabolic parameters.(105) Collagen VI deposition and adipose tissue fibrosis in human WAT is coincident with the presence of 'alternatively activated' (CD150 $)$ ATMs that are known to promote ECM remodeling and wound healing. (107)

One potential emerging mechanism involves the endoplasmic reticulum (ER), the organelle responsible for protein folding, maturation, quality control, and trafficking. When the ER becomes stressed due to the accumulation of newly synthesized unfolded proteins, the unfolded protein response (UPR) is activated. The three branches of the canonical UPR intersect with a variety of inflammatory and stress signaling systems including the NFкB-ІкB kinase (IKK) and JNK-AP1 pathways, as well as networks activated by oxidative stress, all of which can influence metabolism.(108)

A close examination of ER stress and UPR pathways has demonstrated many links to major inflammatory and stress signaling networks, including the activation of the JNK-AP1 and NFkB-IKK pathways $(109,110)$, as well as production of reactive oxygen species (ROS) and nitric oxide.(111,112) Notably, these are also the pathways and mechanisms that play a central role in obesity-induced inflammation and metabolic abnormalities, particularly abnormal insulin action.(65) Given that the UPR is closely integrated with stress signaling, inflammation, and JNK activation and the fact that obesity stresses the ER (due to an increase in synthetic demand, alterations in energy availability, and activation of inflammatory pathways), Hotamisligil have postulated that obesity may lead to ER stress in metabolically active tissues.(108)

Obesity is a condition where the organism needs to adapt to and function under chronic exposure to high energy and nutrient intake. This adaptation alone increases the demand on the synthetic and storage machinery at several sites, including liver, adipose tissue, and pancreas, all of which are central players in metabolic homeostasis. Hence, the major cell types controlling systemic metabolic homeostasis may become highly sensitive to ER stress under conditions of obesity. This is due to increased demands on the synthetic machinery as a result of nutrient excess, saturation of storage capacity, and many other factors, which together create a challenging milieu in which the ER must carry out its regular functions and sustain its proteinfolding capacity.

ER stress and the UPR are connected to inflammatory pathways and may contribute to the production of inflammatory mediators. Conversely, inflammation can also induce or propagate the UPR.(108) Obesity is a state of chronic low-grade systemic inflammation. This chronic inflammation is deeply involved in insulin resistance, which is the underlying condition of T2DM and MetS. A significant advance in our understanding of obesityassociated inflammation and insulin resistance has been recognition of the critical role of ATMs.

Importantly, tissue macrophages are phenotypically heterogeneous and have been characterized according to their activation/polarization state as M1 (or "classically activated" proinflammatory macrophages) or M2 (or "alternatively activated" noninflammatory macrophages. (113-116) In addition to the absolute number of macrophages recruited to adipose tissue, the polarization status of macrophages also influences obesity pathogenesis.

M2 ATMs predominate in lean mice, whereas obesity induces the accumulation of M1 ATMs with high expression of TNF- $\alpha$, IL-6 and inducible nitric oxide synthase,(115) leading to a proinflammatory environment in WAT. M2 macrophages produce anti-inflammatory molecules, including IL-10 and the IL-1 receptor antagonist IL-1RA, and are induced in response to the T helper type 2-associated cytokines IL-4 and IL-13.(115)

Obesity-related events promote the recruitment of M1 macrophages into adipose tissue, and during obesity, M1 macrophages are by far the dominant macrophage population present in fat. Notably, many studies have demonstrated that tipping the balance back in favor of M2 macrophages during obesity promotes improved metabolic function and less adipose inflammation.(117) Consistent with that, the treatment of obese mice with omega-3 fatty acids or thiazolidinediones has been shown to ameliorate metabolic disease through the induction of M2 macrophages. $(118,119)$ It has been discovered that the transcription factor PPAR- $\gamma$ directs the transcriptional programming of M2 macrophages.(120)

\section{Adipose Tissue Dysfunction}

Fat is not homogeneous. Depot-dependent differences among preadipocytes, from which new fat cells arise, appear to be inherent. These inherent mechanisms, combined with local variation in fat-depot cellular composition, circulation, 
and neurological and other factors, probably account for regional differences in fat-tissue size and function. Sex, obesity, or other factors also have fat-depot dependent effects on cellular composition, the paracrine microenvironment, and adipose function. Thus, different fat depots are separate miniorgans.(10)

Immediate questions include whether visceral obesity is a manifestation of a general process that leads to systemic metabolic dysfunction, whether it is causal, or whether subcutaneous fat dysfunction initiates both visceral obesity and metabolic disease. Evidence is mounting in favor of the latter. The relationship between inflammation and MetS is supported by several studies $(65,121-123)$, as is the relationship between increased visceral fat mass and MetS.(124-126) However, there is a paucity of data on SAT biology in the pathogenesis of MetS.(127)

SAT which comprises $\sim 80 \%$ of adipose tissue and is the major source of fatty acids for the liver is readily accessible to study and has been shown to be metabolically correlated to indices of insulin resistance as well as to VAT. (128-131) In addition to intraabdominal fat, investigators have shown that the amount of SAT in subjects with MetS positively correlates with increasing MetS factor scores and negatively correlates with circulating adiponectin levels. (132) Other investigators have also reported that SAT is significantly associated with MetS and increases with the increasing number of MetS features, independent of age and sex.(133) Furthermore, inflammatory cells and processes, such as macrophage infiltration, appear to be important in adipose tissue inflammation. Specifically, investigators have examined abdominal SAT from obese subjects and reported that an inflamed adipose phenotype characterized by tissue macrophage accumulation in crownlike structures (CLSs) is associated with systemic hyperinsulinemia and insulin resistance and impaired endotheliumdependent flow-mediated vasodilation.(134) Macrophage retention in fat was also linked to upregulated tissue CD68 and TNF- $\alpha$ mRNA expressions in addition to increased plasma highsensitivity C-reactive protein (hsCRP) concentrations. As such, Bremer study has focused on the potential role of SAT dysregulation in the syndrome's pathogenesis.(135)

Importantly, there was also a significantly higher release of chemerin from SAT in subjects with MetS which persisted following adjustment for BMI or waist circumference (WC) and age. In addition, there was a significantly lower secretion of omentin from SAT in subjects with MetS which persisted following adjustment for both age and BMI or WC. However, the secretion of both resistin and visfatin from SAT was not significantly different between the MetS and control groups.(135)
In addition, Bremer, et al. have recently demonstrated abnormal circulating and SAT-secreted chemerin and omentin-1 levels in subjects with nascent MetS.(136) Chemerin is a novel adipokine that is produced by both adipose tissue and liver; moreover, it is a chemoattractant for immune cells such as macrophages and promotes adipocyte differentiation.(137) Chemerin levels have also been shown to be higher in obesity, some features of MetS, diabetes, and nonalcoholic fatty liver disease,(138-139) and it appears to induce insulin resistance in skeletalmuscle, the major site of peripheral insulin resistance.(140)

As opposed to chemerin, omentin is predominantly expressed and secreted by VAT $(141,142)$ and appears to have insulin-sensitizing actions.(142) Furthermore, its levels are lower with both obesity and diabetes.(143) This data, as well as data fromother investigators, thus, highlight the importance of SAT dysfunction in subjects with MetS and its contribution to the proinflammatory state and insulin resistance.

\section{Conclusion}

Subcutaneous fat tissue dysfunction, with failed adipogenesis, decreased lipid-storage capacity, and inflammation, could lead to ectopic fat deposition, with expansion of visceral fat as an indicator rather than the cause of lipotoxicity. Therefore, enhancing subcutaneous fat tissue function is potentially a better approach for treating metabolic syndrome than eliminating visceral fat. Indeed, TZDs may work this way. If further experimental results indicate that this speculation has merit, screening for compounds that enhance subcutaneous preadipocyte replication and adipogenesis might lead to effective treatments for preventing complications of metabolic syndrome.

\section{References}

1. Prospective Studies Collaboration, Whitlock G, Lewington S, Sherliker P, Clarke R, Emberson J, et al. Prospective Studies Collaboration. Body-mass index and cause-specific mortality in 900,000 adults: collaborative analyses of 57 prospective studies. Lancet. 2009; 373: 1083-96.

2. Krotkiewski M, Björntorp P, Sjöström L, Smith U. Impact of obesity on metabolism in men and women. Importance of regional adipose tissue distribution. J Clin Invest. 1983; 72: 1150-62.

3. Després JP, Lemieux I. Abdominal obesity and metabolic syndrome. Nature. 2006; 444: 881-7.

4. Neeland IJ, Turer AT, Ayers CR, Powell-Wiley TM, Vega GL, Farzaneh-Far R, et al. Dysfunctional adiposity and the risk of prediabetes and type 2 diabetes in obese adults. JAMA. 2012; 308: $1150-9$. 
5. Gustafson B, Hammarstedt A, Hedjazifar S, Smith U. Restricted adipogenesis in hypertrophic obesity. The role of WISP2, WNT, and BMP4. Diabetes. 2013; 62: 2997-3004.

6. Kirkland JL, Hollenberg CH, Gillon WS. Age, anatomic site, and the replication and differentiation of adipocyte precursors. Am J Physiol. 1990; 258: C206-10.

7. Tchkonia T, Corkey BE, Kirkland JL. Current Views of the Fat Cell as an Endocrine Cell: Lipotoxicity, Vol. 26. In: Bray GA, Ryan DH, editors. Endocrine Updates: Overweight and the Metabolic Syndrome. New York: Springer; 2006. p.105-18.

8. Thomou T, Tchkonia T, Kirkland JL. Cellular and molecular basis of functional differences among fat depots. In: Leff TA, Granneman JG, editors. Adipose Tissue in Health and Disease. Weinheim: Wiley; 2010. p.21-47.

9. Mauer MM, Harris RB, Bartness TJ. The regulation of total body fat: lessons learned from lipectomy studies. Neurosci Biobehav Rev. 2001; 25: 15-28.

10. Tchkonia T, Thomou T, Zhu Y, Keragiannides I, Pothoulakis C, Jensen D, et al. Mechanisms and metabolic implications of regional differences among fat depots. Cell Metab. 2013; 17: 644-56.

11. Frayn K. Adipose tissue as a buffer for daily lipid flux. Diabetologia. 2002; 45: 1201-10.

12. Bjørndal B, Burri L, Staalesen V, Skorve J, Berge RK. Different adipose depots: their role in the development of metabolic syndrome and mitochondrial response to hypolipidemic agents. J Obes. 2011; 2011: 490650. doi: 10.1155/2011/490650.

13. Cannon B, Nedergaard J. Brown adipose tissue: function and physiological significance. Physiol Rev. 2003; 84: 277-359.

14. Fantuzzi G. Adipose tissue, adipokines, inflammation. J Allergy Clin Immunol. 2005; 115: 911-9.

15. Iacobellis G, Pistilli D, Gucciardo M, Leonetti F, Miraldi F, Brancaccio $\mathrm{G}$, et al. Adiponectin expression in human epicardial adipose tissue in vivo is lower in patients with coronary artery disease. Cytokine. 2005; 29: 251-5.

16. Iacobellis G, Willens HJ. Echocardiographic epicardial fat: a review of research and clinical applications. J Am Soc Echocardiogr. 2009; 22: 1311-9.

17. Ouwens DM, Sell H, Greulich S, Eckel J. The role of epicardial and perivascular adipose tissue in the pathophysiology of cardiovascular disease. J Cell Mol Med. 2010; 14: 2223-4.

18. Iozzo P. Myocardial, perivascular, and epicardial fat. Diabetes Care. 2011; 34 Suppl 2: S371-9.

19. Yudkin JS, Eringa E, Stehouwer CDA. Vasocrine signalling from perivascular fat: a mechanism linking insulin resistance to vascular disease. Lancet. 2005; 365: 1817-20.

20. Fazeli PK, Horowitz MC, MacDougald OA, Scheller EL, Rodeheffer MS, Rosen CJ, et al. Marrow fat and bone - new perspectives. J Clin Endocrinol Metab. 2013; 98: 935-45.

21. Tchoukalova YD, Votruba SB, Tchkonia T, Giorgadze N, Kirkland JL, Jensen MD. Regional differences in cellular mechanisms of adipose tissue gain with overfeeding. Proc Natl Acad Sci USA 2010; 107, 18226-31.

22. Tchkonia T, Morbeck DE, Von Zglinicki T, Van Deursen J, Lustgarten $\mathrm{J}$, Scrable H, et al. Fat tissue, aging, and cellular senescence. Aging Cell. 2010; 9: 667-84.

23. Cawthorn W, Scheller E, MacDougald OA. Adipose tissue stem cells meet preadipocyte commitment: going back to the future. J Lipid Res. 2012; 53: 227-42.

24. Hellman B, Hellerstrom C. Cell renewal in the white and brown fat tissue of the rat. Acta Pathol Microbiol Scand. 1961; 51: 347-53.

25. Hirsch J, Han PW. Cellularity of rat adipose tissue: effects of growth, starvation, and obesity. J Lipid Res. 1969; 10: 77-82.

26. Lemonnier D. Effect of age, sex, and sites on the cellularity of the adipose tissue in mice and rats rendered obese by a high-fat diet. J
Clin Invest. 1972; 51: 2907-15.

27. Häger A, Sjöstrm L, Arvidsson B, Björntorp P, Smith U. Body fat and adipose tissue cellularity in infants: a longitudinal study. Metabolism . 1977; 26 : 607-14.

28. Bertrand HA, Masoro EJ, Yu BP. Increasing adipocyte number as the basis for perirenal depot growth in adult rats. Science. 1978; 201: 1234-5.

29. Faust IM, Johnson PR, Stern JS, Hirsch J. 1978. Diet-induced adipocyte number increase in adult rats: a new model of obesity. Am. J. Physiol. 1978; 235: E279 - 86 .

30. Knittle JL, Timmers K, Ginsberg-Fellner F, Brown RE, Katz DP. The growth of adipose tissue in children and adolescents. Crosssectional and longitudinal studies of adipose cell number and size. J Clin Invest. 63: 239-246.

31. Spalding KL, Arner E, Westermark PO, Bernard S, Buchholz BA, Bergmann O, et al. Dynamics of fat cell turnover in humans. Nature. 2008; 453: 783-7.

32. Rigamonti A, Brennand K, Lau F, Cowan CA. Rapid cellular turnover in adipose tissue. PLoS ONE. 2011; 6: e17637. doi: 10.1371/ journal.pone.0017637.

33. Prins JB, O'Rahilly S. Regulation of adipose cell number in man. Clin Sci (Lond). 1997; 92: 3-11.

34. Garaulet M, Hernandez-Morante JJ, Lujan J, Tebar FJ, Zamora S. Relationship between fat cell size and number and fatty acid composition in adipose tissue from different fat depots in overweight obese humans. Int J Obes (London). 2006; 6: 899-905.

35. Hausman DB, DiGirolamo M, Bartness TJ, Hausman GJ, Martin RJ The biology of white adipocyte proliferation. Obesity Rev. 2001; 2: 239-54.

36. Gregoire F. Adipocyte differentiation: from fibroblast to endocrine cell. Exp Biol Med. 2001; 226: 997-1002.

37. Fajas L. Adipogenesis: a cross-talk between cell proliferation and cell differentiation. Ann Med. 2003; 35: 79-85.

38. Smas CM, Sul HS. Control of adipocyte differentiation. Biochem J. 1995; 309: 697-710.

39. Ailhaud G, Grimaldi P, Negrel R. Cellular and molecular aspects of adipose tissue development. Annu Rev Nutr. 1992; 12: 207-33.

40. Rodbell M. Metabolism of isolated fat cells. I. Effects of hormones on glucose metabolism and lipolysis. J Biol Chem. 1964; 239: 375-80.

41. Ng CW, Poznanski WJ, Borowiecki M, Reimer G. Differences in growth in vitro of adipose cells from normal and obese patients. Nature. 1971; 231: 445.

42. Poznanski WJ, Waheed I, Van R. Human fat cell precursors. Morphologic and metabolic differentiation in culture. Lab. Invest. 1973; $29: 570-6$.

43. Van RL, Bayliss CE, Roncari DA. Cytological and enzymological characterization of adult human adipocyte precursors in culture. J Clin Invest. 1976; 58 : 699-704.

44. Farmer SR. Transcriptional control of adipocyte formation. Cell Metab. 2006; 4: 263-73

45. Rosen ED, MacDougald OA. Adipocyte differentiation from the inside out. Nat Rev Mol Cell Biol. 2006; 7: 885-96.

46. Christodoulides C, Lagathu C, Sethi JK, Vidal-Puig A. Adipogenesis and WNT signalling. Trends Endocrinol Metab. 2009; 20: 16-24.

47. Lefterova MI, Lazar MA. New developments in adipogenesis. Trends Endocrinol Metab. 2009; 20: 107-14.

48. Lowe CE, O'Rahilly S, Rochford JJ. Adipogenesis at a glance. J Cell Sci. 2011; 124: 2681-6.

49. Eguchi J, Yan QW, Schones DE, Kamal M, Hsu CH, Zhang MQ, et al. Interferon regulatory factors are transcriptional regulators of adipogenesis. Cell Metab. 2008; 7: 86-94.

50. Nielsen R, Pedersen TA, Hagenbeek D, Moulos P, Siersbaek R, Megens E, et al. Genome-wide profi ling of PPARgamma:RXR and RNA polymerase II occupancy reveals temporal activation of 
distinct metabolic pathways and changes in RXR dimer composition during adipogenesis. Genes Dev. 2008; 22: 2953-67.

51. Steger DJ, Grant GR, Schupp M, Tomaru T, Lefterova MI, Schug $\mathrm{J}$, et al. Propagation of adipogenic signals through an epigenomic transition state. Genes Dev. 2010; 24: 1035-44.

52. Siersbæk R, Nielsen R, John S, Sung MH, Baek S, Loft A, et al. Extensive chromatin remodeling and establishment of transcription factor 'hotspots' during early adipogenesis. EMBO J. 2011; 30: 1459-72.

53. Arner E, Westermark PO, Spalding KL, Britton T, Rydén M, Frisén $\mathrm{J}$, et al. Adipocyte turnover: relevance to human adipose tissue morphology. Diabetes. 2010; 59: 105-9.

54. Talchai C, Xuan S, Lin HV, Sussel L, Accili D. Pancreatic b cell dedifferentiation as a mechanism of diabetic $\mathrm{b}$ cell failure. Cell. 2012; 150: 1223-34.

55. Isakson P, Hammarstedt A, Gustafson B, Smith U. Impaired preadipocyte differentiation in human abdominal obesity: role of Wnt, tumor necrosis factor-alpha, and inflammation. Diabetes. 2009; 58: 1550-7.

56. Clevers H, Nusse R. Wnt/b-catenin signaling and disease. Cell. 2012; 149: $1192-205$

57. Wu Z, Rosen ED, Brun R, Hauser S, Adelmant G, Troy AE, et al. Cross-regulation of C/EBP alpha and PPAR gamma controls the transcriptional pathway of adipogenesis and insulin sensitivity. Mol Cell. 1999; 3: 151-8.

58. Gustafson B, Eliasson B, Smith U. Thiazolidinediones increase the winglesstype MMTV integration site family (WNT) inhibitor Dickkopf-1 in adipocytes: a link with osteogenesis. Diabetologia. 2010; 53: 536-40.

59. Gustafson B, Smith U. The WNT inhibitor Dickkopf 1 and bone morphogenetic protein 4 rescue adipogenesis in hypertrophic obesity in humans. Diabetes. 2012; 61: 1217-24.

60. Bowers RR, Kim JW, Otto TC, Lane MD. Stable stem cell commitment to the adipocyte lineage by inhibition of DNA methylation: role of the BMP-4 gene. Proc Natl Acad Sci USA. 2006; 103: 13022-7.

61. Tseng YH, Kokkotou E, Schulz TJ, Huang TL, Winnay JN, Taniguchi $\mathrm{CM}$, et al. New role of bone morphogenetic protein 7 in brown adipogenesis and energy expenditure. Nature. 2008; 454: 1000-4.

62. Camp HS, Ren D, Leff T. Adipogenesis and fat-cell function in obesity and diabetes. Trends Mol Med. 2002; 8: 442-7.

63. Sethi JK. Obesity: adipogenesis and insulin resistance. IDrugs. 2000; 3: 884-6.

64. Zeyda M, Stulnig TM. Obesity, inflammation, and insulin resistance a mini-review. Gerontology. 2009; 55: 379-86 .

65. Hotamisligil GS. Inflammation and metabolic disorders. Nature. 2006; 444: 860-7

66. Andersson CX, Gustafson B, Hammarstedt A, Hedjazifar S, Smith $\mathrm{U}$. Inflamed adipose tissue, insulin resistance and vascular injury. Diabetes Metab Res Rev. 2008; 24: 595-603.

67. Gustafson B, Hammarstedt A, Andersson CX, Smith U. Inflamed adipose tissue: a culprit underlying the metabolic syndrome and atherosclerosis. Arterioscler Thromb Vasc Biol. 2007; 27: 2276-83.

68. Maury E, Brichard SM. Adipokine dysregulation, adipose tissue inflammation and metabolic syndrome. Mol Cell Endocrinol. 2010; 314: 1-16.

69. Arner P, Arner E, Hammarstedt A, Smith U. Genetic predisposition for type 2 diabetes, but not for overweight/obesity, is associated with a restricted adipogenesis. PLoS One. 2011; 6: e18284. doi: 10.1371/journal.pone.0018284.

70. Jansson PA, Pellmé F, Hammarstedt A, Sandqvist M, Brekke H, Caidahl $\mathrm{K}$, et al. A novel cellular marker of insulin resistance and early atherosclerosis in humans is related to impaired fat cell differentiation and low adiponectin. FASEB J. 2003; 17: 1434-40.

71. Rondinone CM, Wang LM, Lonnroth P, Wesslau C, Pierce JH,
Smith U. Insulin receptor substrate (IRS) 1 is reduced and IRS2 is the main docking protein for phosphatidylinositol 3-kinase in adipocytes from subjects with non-insulin-dependent diabetes mellitus. Proc Natl Acad Sci USA. 1997; 94: 4171-5.

72. Kim JY, van de Wall E, Laplante M, Azzara A, Trujillo ME, Hofmann SM, et al. Obesity-associated improvements in metabolic profile through expansion of adipose tissue. J Clin Invest. 2007; 117: 262137.

73. Weisberg SP, McCann D, Desai M, Rosenbaum M, Leibel RL, Ferrante AW Jr. Obesity is associated with macrophage accumulation in adipose tissue. J Clin Invest. 2003; 112: 1796-808.

74. McQuaid SE, Hodson L, Neville MJ, Dennis AL, Cheeseman J, Humphreys SM, et al. Downregulation of adipose tissue fatty acid trafficking in obesity: a driver for ectopic fat deposition? Diabetes. 2011; 60: 47-55.

75. Cinti S, Mitchell G, Barbatelli G, Murano I, Ceresi E, Faloia E, et al. Adipocyte death defines macrophage localization and function in adipose tissue of obese mice and humans. J Lipid Res. 2005; 46: 2347-55.

76. Fischer-Posovszky P, Wang QA, Asterholm IW, Rutkowski JM, Scherer PE. Targeted deletion of adipocytes by apoptosis leads to adipose tissue recruitment of alternatively activated M2 macrophages. Endocrinology. 2011; 152: 3074-81.

77. Okuno A, Tamemoto H, Tobe K, Ueki K, Mori Y, Iwamoto K, et al. Troglitazone increases the number of small adipocytes without the change of white adipose tissue mass in obese Zucker rats. J Clin Invest. 1998; 101: 1354-61.

78. Cusi K. Role of obesity and lipotoxicity in the development of nonalcoholic steatohepatitis: pathophysiology and clinical implications. Gastroenterology. 2012; 142: 711-25

79. Denis GV, Obin MS. "Metabolically healthy obesity": origins and implications. Mol Aspects Med. 2013; 34: 59-70.

80. Finucane MM, Stevens GA, Cowan MJ, Danaei G, Lin JK, Paciorek CJ, et al. Global Burden of Metabolic Risk Factors of Chronic Diseases Collaborating Group (Body Mass Index). National, regional, and global trends in body-mass index since 1980: systematic analysis of health examination surveys and epidemiological studies with 960 country-years and $9 \cdot 1$ million participants. Lancet. 2011; 377: $557-$ 67.

81. Hedley AA, Ogden CL, Johnson CL, Carroll MD, Curtin LR, Flegal KM. Prevalence of overweight and obesity among US children, adolescents, and adults, 1999-2002. JAMA. 2004; 291: 2847-50.

82. Adams KF, Schatzkin A, Harris TB, Kipnis V, Mouw T, BallardBarbash R, et al. Overweight, obesity, and mortality in a large prospective cohort of persons 50 to 71 years old. N Engl J Med. 2006; 355: 763-78.

83. Eckel RH, Kahn R, Robertson RM, Rizza RA. Preventing cardiovascular disease and diabetes: a call to action from the American Diabetes Association and the American Heart Association. Diabetes Care. 2006; 29: 1697-9.

84. Hossain P, Kawar B, El Nahas M. Obesity and diabetes in the developing world - a growing challenge. N Engl J Med. 2007; 356: 213-5

85. Ferrannini E, Natali A, Bell P, Cavallo-Perin P, Lalic N, Mingrone G, European Group for the Study of Insulin Resistance (EGIR). Insulin resistance and hypersecretion in obesity. J Clin Invest. 1997; 100: 1166-73.

86. Bonora E, Kiechl S, Willeit J, Oberhollenzer F, Egger G, Targher G, et al. Prevalence of insulin resistance in metabolic disorders: the Bruneck Study. Diabetes. 1998; 47: 1643-9.

87. Brochu M, Tchernof A, Dionne IJ, Sites CK, Eltabbakh GH, Sims EA, et al. What are the physical characteristics associated with a normal metabolic profile despite a high level of obesity in postmenopausal women? J Clin Endocrinol Metab. 2001; 86: 1020-5. 
88. Sims EA. Are there persons who are obese, but metabolically healthy? Metabolism. 2001; 50: 1499-504.

89. Karelis AD, Brochu M, Rabasa-Lhoret R. Can we identify metabolically healthy but obese individuals (MHO)? Diabetes Metab. 2004; 30: 569-72.

90. Meigs JB, Wilson PW, Fox CS, Vasan RS, Nathan DM, Sullivan LM, et al. Body mass index, metabolic syndrome, and risk of type 2 diabetes or cardiovascular disease. J Clin Endocrinol Metab. 2006; 91: 2906-12.

91. Wildman RP, Muntner P, Reynolds K, McGinn AP, Rajpathak S, Wylie-Rosett J, et al. The obese without cardiometabolic risk factor clustering and the normal weight with cardiometabolic risk factor clustering: prevalence and correlates of 2 phenotypes among the US population (NHANES 1999-2004). Arch Intern Med. 2008; 168 : 1617-24.

92. Stefan N, Kantartzis K, Machann J, Schick F, Thamer C, Rittig K, et al. Identification and characterization of metabolically benign obesity in humans. Arch Intern Med. 2008; 168: 1609-16.

93. Karelis AD. Metabolically healthy but obese individuals. Lancet. 2008; 372: 1281-3.

94. Messier V, Karelis AD, Prud'homme D, Primeau V, Brochu M, Rabasa-Lhoret R. Identifying metabolically healthy but obese individuals in sedentary postmenopausal women. Obesity (Silver Spring). 2010; 18: 911-7.

95. Primeau V, Coderre L, Karelis AD, Brochu M, Lavoie ME, Messier $\mathrm{V}$, et al. Characterizing the profile of obese patients who are metabolically healthy. Int J Obes (Lond). 2011; 35: 971-81.

96. Klöting N, Fasshauer M, Dietrich A, Kovacs P, Schön MR, Kern M, et al. Insulin - sensitive obesity. Am J Physiol Endocrinol Metab. 2010; 299: E506-15.

97. Spencer M, Yao-Borengasser A, Unal R, Rasouli N, Gurley CM, Zhu $\mathrm{B}$, et al. Adipose tissue macrophages in insulin-resistant subjects are associated with collagen VI and fibrosis and demonstrate alternative activation. Am J Physiol Endocrinol Metab. 2010; 299: E1016-27.

98. Pasarica M, Gowronska-Kozak B, Burk D, Remedios I, Hymel $\mathrm{D}$, Gimble J, et al. Adipose tissue collagen VI in obesity. J Clin Endocrinol Metab. 2009; 94: 5155-62.

99. Huang Y, Yan X, Zhu MJ, McCormick RJ, Ford SP, Nathanielsz $\mathrm{PW}$, et al. Enhanced transforming growth factor-beta signaling and fibrogenesis in ovine fetal skeletal muscle of obese dams at late gestation. Am J Physiol Endocrinol Metab. 2010; 298 :E1254-60.

100. Dubois SG, Heilbronn LK, Smith SR, Albu JB, Kelley DE, Ravussin E. Look AHEAD Adipose Research Group, Decreased expression of adipogenic genes in obese subjects with type 2 diabetes. Obesity (Silver Spring). 2006; (1): 1543-52.

101. Trayhurn P, Wang B, Wood IS. Hypoxia in adipose tissue: a basis for the dysregulation of tissue function in obesity? Br J Nutr. 2008; 100: 227-35.

102. Chun TH, Hotary KB, Sabeh F, Saltiel AR, Allen ED, Weiss SJ. A pericellular collagenase directs the 3-dimensional development of white adipose tissue. Cell. 2006; 125: 577-91.

103. Henegar C, Tordjman J, Achard V, Lacasa D, Cremer I, Guerre-Millo $\mathrm{M}$, et al. Adipose tissue transcriptomic signature highlights the pathological relevance of extracellular matrix in human obesity. Genome Biol. 2008; 9: R14. doi: 10.1186/gb-2008-9-1-r14.

104. Halberg N, Khan T, Trujillo ME, Wernstedt-Asterholm I, Attie AD, Sherwani $\mathrm{S}$, et al. Hypoxia-inducible factor 1alpha induces fibrosis and insulin resistance in white adipose tissue. Mol Cell Biol. 2009; 29: 4467-83.

105. Khan T, Muise ES, Iyengar P, Wang ZV, Chandalia M, Abate N, et al. Metabolic dysregulation and adipose tissue fibrosis: role of collagen VI. Mol Cell Biol. 2009; 29: 1575-91.

106. Divoux A, Tordjman J, Lacasa D, Veyrie N, Hugol D, Aissat A, et al. Fibrosis in human adipose tissue: composition, distribution, and link with lipid metabolism and fat mass loss. Diabetes. 2010; 59: 2817-25.

107. Shaul ME, Bennett G, Strissel KJ, Greenberg AS, Obin MS. Dynamic, M2-like remodeling phenotypes of $\mathrm{CD} 11 \mathrm{c}+$ adipose tissue macrophages during high fat diet-induced obesity in mice. Diabetes. 2010; 59: 1171-81.

108. Hotamisligil GS. Endoplasmic reticulum stress and the inflammatory basis of metabolic disease. Cell. 2010; 140: 900-17.

109. Deng J, Lu PD, Zhang Y, Scheuner D, Kaufman RJ, Sonenberg N, et al. Translational repression mediates activation of nuclear factor kappa B by phosphorylated translation initiation factor 2. Mol Cell Biol. 2004; 24: 10161-8.

110. Hu P, Han Z, Couvillon AD, Kaufman RJ, Exton JH. Autocrine tumor necrosis factor alpha links endoplasmic reticulum stress to the membrane death receptor pathway through IRE1alpha-mediated NFkappaB activation and down-regulation of TRAF2 expression. Mol Cell Biol. 2006; 26: 3071-84.

111. Cullinan SB, Diehl JA. Coordination of ER and oxidative stress signaling: the PERK/Nrf2 signaling pathway. Int J Biochem Cell Biol. 2006; 38: 317-32.

112. Gotoh T, Mori M. Nitric oxide and endoplasmic reticulum stress. Arterioscler Thromb Vasc Biol. 2006; 26: 1439-46.

113. Ota T. Chemokine system link obesity to insulin resistance. Diabetes Metab J. 2013; 37: 165-72.

114. Mantovani A, Sica A, Sozzani S, Allavena P, Vecchi A, Locati M. The chemokine system in diverse forms of macrophage activation and polarization. Trends Immunol. 2004; 25: 677-86.

115. Lumeng CN, Bodzin JL, Saltiel AR. Obesity induces a phenotypic switch in adipose tissue macrophage polarization. J Clin Invest. 2007; 117: 175-84.

116. Odegaard JI, Ricardo-Gonzalez RR, Goforth MH, Morel CR, Subramanian V, Mukundan L, et al. Macrophage-specific PPARgamma controls alternative activation and improves insulin resistance. Nature. 2007; 447: 1116-20.

117. Patsouris D, Li PP, Thapar D, Chapman J, Olefsky JM, Neels JG. Ablation of CD11c-positive cells normalizes insulin sensitivity in obese insulin resistant animals. Cell Metab. 2008; 8: 301-9.

118. Oh DY, Talukdar S, Bae EJ, Imamura T, Morinaga H, Fan W, et al. GPR120 is an omega-3 fatty acid receptor mediating potent antiinflammatory and insulin-sensitizing effects. Cell. 2010; 142: 68798.

119. Bouhlel MA, Derudas B, Rigamonti E, Dièvart R, Brozek J, Haulon $\mathrm{S}$, et al. PPARgamma activation primes human monocytes into alternative M2 macrophages with anti-inflammatory properties. Cell Metab. 2007; 6: 137-143.

120. Chawla A, Nguyen KD, Goh YP. Macrophage-mediated inflammation in metabolic disease. Nat Rev Immunol. 2011; 11: 738-49.

121. Eckel RH, Grundy SM, Zimmet PZ. The metabolic syndrome. Lancet. 2005; 365: 1415-28.

122. Cornier MA, Dabelea D, Hernandez TL, Lindstrom RC, Steig AJ, Stob NR, et al. The metabolic syndrome. Endocr Rev. 2008; 29: 777-822.

123. Monteiro R, Azevedo I. Chronic inflammation in obesity and the metabolic syndrome. Mediators Inflamm. 2010; 2010. pii: 289645. doi: 10.1155/2010/289645.

124. Després JP, Lemieux S, Lamarche B, Prud'homme D, Moorjani S, Brun LD, et al. The insulin resistance dyslipidemic syndrome: contribution of visceral obesity and therapeutic implications. Int J Obes Relat Metab Disord. 1995; 19 Suppl 1: S76-86.

125. Després JP. Is visceral obesity the cause of the metabolic syndrome? Ann Med. 2006; 38: 52-63.

126. Fox CS, Massaro JM, Hoffmann U, Pou KM, Maurovich-Horvat $\mathrm{P}$, Liu CY, et al, Abdominal visceral and subcutaneous adipose tissue compartments: association with metabolic risk factors in the 
framingham heart study. Circulation. 2007; 116: 39-48.

127. Porter SA, Massaro JM, Hoffmann U, Vasan RS, O'Donnel CJ, Fox CS. Abdominal subcutaneous adipose tissue: a protective fat depot? Diabetes Care. 2009; 32: 1068-75.

128. Goodpaster BH, Thaete FL, Simoneau JA, Kelley DE. Subcutaneous abdominal fat and thigh muscle composition predict insulin sensitivity independently of visceral fat. Diabetes. 1997; 46: 1579 . 85.

129. Abate N, Garg A, Peshock RM, Stray-Gundersen J, Grundy SM. Relationships of generalized and regional adiposity to insulin sensitivity in men. J Clin Invest. 1995; 96: 88-98.

130. Abate N, Garg A, Peshock RM, Stray-Gundersen J, Adams-Huet B, Grundy SM. Relationship of generalized and regional adiposity to insulin sensitivity in men with NIDDM. Diabetes. 1996; 45: 168493.

131. Ferreira I, Henry RM, Twisk JW, van Mechelen W, Kemper HC, Stehouwer CD, et al. The metabolic syndrome, cardiopulmonary fitness, and subcutaneous trunk fat as independent determinants of arterial stiffness: the Amsterdam Growth and Health Longitudinal Study. Arch Intern Med. 2005; 165: 875-82.

132. Salmenniemi U, Ruotsalainen E, Pihlajamäki J, Vauhkonen I, Kainulainen S, Punnonen K, et al. Multiple abnormalities in glucose and energy metabolism and coordinated changes in levels of adiponectin, cytokines, and adhesion molecules in subjects with metabolic syndrome. Circulation. 2004; 110: 3842-8.

133. Carr DB, Utzschneider KM, Hull RL, Kodama K, Retzlaff BM, Brunzell JD, et al.,Intraabdominal fat is a major determinant of the National Cholesterol Education Program Adult Treatment Panel III criteria for themetabolic syndrome. Diabetes. 2004; 53: 2087-94.

134. Apovian CM, Bigornia S, Mott M, Meyers MR, Ulloor J, Gagua M, et al. Adipose macrophage infiltration is associated with insulin resistance and vascular endothelial dysfunction in obese subjects. Arterioscler Thromb Vasc Biol. 2008; 28: 1654-9.

135. Bremer AA, Jialal I. Adipose tissue dysfunction in nascent metabolic syndrome. J Obes. 2013; 2013: 393192. doi: 10.1155/2013/393192.

136. Jialal I, Devaraj S, Adams-Huet B, Chen X, Kaur H. Increased cellular and circulating biomarkers of oxidative stress in nascent metabolic syndrome. J Clin Endocrinol Metab. 2012; 97: E1844-50.

137. Ernst MC, Sinal CJ. Chemerin: at the crossroads of inflammation and obesity. Trends Endocrinol Metab. 2010; 21: 660-7.

138. Bozaoglu K, Segal D, Shields KA, Cummings N, Curran JE, Comuzzie AG, et al. Chemerin is associated with metabolic syndrome phenotypes in a Mexican-American population. J Clin Endocrinol Metab. 2009; 94: 3085-8.

139. Sell H, Divoux A, Poitou C, Basdevant A, Bouillot JL, Bedossa P, et al. Chemerin correlates with markers for fatty liver in morbidly obese patients and strongly decreases after weight loss induced by bariatric surgery. J Clin Endocrinol Metab. 2010; 95: 2892-6.

140. Sell H, Laurencikiene J, Taube A, Eckardt K, Cramer A, Horrighs A, et al. Chemerin is a novel adipocyte-derived factor inducing insulin resistance in primary human skeletal muscle cells. Diabetes. 2009; 58: 2731-40.

141. Schäffler A, Neumeier M, Herfarth H, Fürst A, Schölmerich J, Büchler C. Genomic structure of human omentin, a new adipocytokine expressed in omental adipose tissue. Biochim Biophys Acta. 2005; 1732: 96-102.

142. Tan BK, Adya R, Randeva HS. Omentin: a novel link between inflammation, diabesity, and cardiovascular disease. Trends Cardiovasc Med. 2010; 20: 143-8.

143. de Souza Batista CM, Yang RZ, Lee MJ, Glynn NM, Yu DZ, Pray J, et al. Omentin plasma levels and gene expression are decreased in obesity. Diabetes. 2007; 56: 1655-61. 